Iva Klepić, mag.oec. ${ }^{1}$

Mirela Mabić, MSc. ${ }^{2}$

Danijela Madžar, PhD. ${ }^{3}$

\title{
RECRUITMENT AND SELECTION OF HUMAN RESOURCES AND ORGANIZATIONAL CREATIVITY IN SMALL AND MEDIUM-SIZED ENTERPRISES
}

\begin{abstract}
In modern business conditions, human resources have become the most important resource of enterprises, and many authors point out that this is especially true for SMEs, in which, due to their specificity, human resources create a competitive advantage of the company and affect its survival and development.

SMEs are faced with a strong, global competition of large enterprises and in order to survive and grow in the market, they must find specific strengths within themselves, develop and use them. Creativity is one of the most powerful tools that enable SMES competitiveness, survival and development in the market.

The basic objective of this research is to determine whether there is a correlation between recruitment and selection of human resources and organizational creativity in SMEs.

The survey was conducted in SMEs in the Federation of B\&H in 2019. An original questionnaire was created for the research, which collected the opinion of top managers on the recruitment and selection of human resources and organizational creativity in small and medium-sized enterprises.

Data have been analysed using IBM SPSS Statistic 25.0. From the statistical procedures, the following were used: Shapiro-Wilk's test, Pearson's coefficient of correlation, Mann-Whitney $U$ test and t-test for independent samples.

The results of the survey showed that there is a correlation between the recruitment and selection of human resources and organizational creativity in SMEs and that there are differences in the correlation between the recruitment and selection of human resources and organizational creativity in the enterprises in terms of their size.
\end{abstract}

Key words: creativity, human resources, recruiting, small and medium enterprises, selection,

JEL: $M 12, M 51,015$

1 University of Mostar, e-mail: iva.klepic@sum.ba

2 Higher Assistant, University of Mostar, e-mail: mirela.mabic@ef.sum.ba

3 Assistant Professor, University of Mostar, e-mail: danijela.madzar@fpmoz.sum.ba 


\section{INTRODUCTION}

Small and medium-sized enterprises (SMEs) are a major driver of development, innovation, competitiveness and employment in Europe. In today's modern business environment, with increasing and globalized competition, and in the market struggles with large, international companies, SMEs are striving to fight for their survival and development. In order to be able to survive and grow, SMEs rely heavily on human resources. Human resources are the most important factor of business success and represent a key strategic and competitive advantage of any organization. People are the ones who, with their knowledge, skills, ability, motivation, loyalty and creativity, using and managing material, financial and information resources to the greatest extent, affect the business result, development and survival of every enterprise. This is especially true for human resources in small and medium-sized enterprises which due to their size are looking the mainstay in uniqueness of human resources, their quality, motivation, innovation and creativity in the competition on the globalized market. They are unique for any enterprise and they represent the living factor of every organization.

Human resource management has been given a primary role in every enterprise and has become a key business function. One of the most important tasks of management is to find competent candidates and employees and to select those who can most influence the achievement of the vision, mission and objectives of the enterprise. Lately, there is an increased demand of young people with general development potentials, who are flexible, innovative, creative, communicative, prone to teamwork and a dynamic work environment, while concrete knowledge of doing a particular job is in the background.

According to Madžar (2018, p. 4), a study on creativity resulted in the creation of a study by Adobe Systems Incorporated (2012), which was conducted on a sample of 5,000 people in the USA, UK, Germany, France and Japan. The study found out that 8 out of 10 people believe that encouraging creativity is the most important for economic growth, and nearly two-thirds of respondents believe that creativity is valuable to society. The results of the survey also showed that $75 \%$ of the respondents think that they are pressured in the workplace to be productive rather than creative, and that only $39 \%$ consider themselves creative.

Vicari (1998) described high organizational creativity as a continuous engagement of employees and managers in creative efforts, which resulted in innovation.

Encouraging creativity and innovation is the primary objective of management in every organization. 
According to Goldstein (2016) creativity is the driver of innovation and a key factor in the development of personal, professional, entrepreneurial and social skills. Creativity or creative productivity is the result of the mental process of creating new or partially new ideas, approaches, activities or specific things that contain originality. (Madžar 2018, p. 10)

According to Zahaire, M. and Osoian, C. (2013, p. 89) recruitment process is an important prerequisite stage in a successful hiring process. Since the quality of the recruitment process is crucial for the effectiveness of the employee selection, small companies need to invest more resources in recruiting good candidates.

The main objective of this research is to determine if recruitment and selection, as key activities of human resources management, are in correlation with creativity in SMEs, and if there is a difference in the correlation between enterprises in terms of size of the enterprise, i.e. small and medium-sized enterprises.

\section{Theoretical Background}

\subsection{Recruiting and Selection of Human Resources}

People and their potentials are the most important factor of business success and a key strategic and competitive advantage of enterprise. They are the ones who mobilize material resources and use financial resources. Successful use of material and financial resources depends on their quality, motivation and work engagement, and therefore, even the best and most comprehensive resources without competent human engagement will not produce positive results. The organization is a reflection of its people and the success of the organization depends on the quality of the talent employed by the organization.

According to Bahtijarević-Šiber (1999, p. 16-17), human resources means the total knowledge, skills, abilities, creative possibilities, motivation and loyalty of an organization or society. Human resources management is a series of related activities and tasks of management and organizations aiming to ensure the adequate number and structure of employees, their knowledge, skills, interests, motivations and behaviors necessary to achieve the current, developmental and strategic objectives of the organization.

In the late 1990s, a landmark study conducted by McKinsey and Company focused on personnel talent as the most important corporate resource for organizations. As noted by researchers Jerome Rosow and John Hickey, as organizations now place a premium on human capital, a critical question centres on how people become part of an organization (Michaels,

Handfield-Jones, \& Axelrod 2001, as cited in Goldstein, Pulakos, Passmore, \& Semedo 2017). 
According to Barber (1998) and Rynes (1989) finding the right employees for any organization requires an intricate combination of systems working in tandem. Company needs effective systems to attract a suitable and substantial pool of applicants. They need to screen and select the most appropriate candidates, and ultimately they need to convince those selected to accept the job offer. Despite the interdependence of these systems, much of the literature on staffing organizations focuses on screening and selection, with far less attention being paid to the attraction functions. If an organization fails to attract sufficient quantities of candidates with the right qualities, the selection system will not be effective regardless of its sophistication (Boudreau \& Rynes 1985).

After defining the vision and mission, the objectives to be achieved (starting with those in the long term, and those in the medium and short term, i.e. operational objectives) and a strategy for the achievement of the objectives, the enterprise must also include in its plans (strategic, tactical and operational) the human resources that will achieve those objectives. (Lesko Bošnjak \& Klepić 2013)

For Bahtijarević-Šiber (Sikavica, Bahtijarević-Šiber \& Pološki Vokić 2008, p. 655) human resources planning is the process by which organizational strategies, business plans and objectives are translated into assessing the required quantity and quality of human resources for their successful implementation, achieving the desired organizational success and development in the future.

According to Newman and Sheikh (2014, p. 416) recruitment and selection in SMEs are generally done on an informal, ad hoc basis through the use of practices which are convenient and inexpensive (Heneman \& Berkely 1999; Hornsby \& Kuratko 2003). Employee recruitment is often conducted through the use of personal connections and word of mouth rather than formally, via an established application and selection process (Carroll et al. 1999; Gilbert \& Jones 2000; Kotey \& Sheridan 2001; Cooke 2005).

Once the planning of human resources has been completed, the recruitment process should start which is defined as a process of creating a group of qualified candidates for the vacancies within the organizations. In both professional and non-professional areas, recruitment will include an attempt to locate a diverse applicant pool with the necessary qualifications and potential, and communicate to them the available employment opportunities (Raghavi \& Gopinathan 2013).

According to Klepić (2019) recruitment is a process of attracting candidates for job vacancies, who have the abilities, skills and features required for successful job performance and setting objectives. Includes searching, attracting and providing candidates, and choosing the ones who best match job vacancy requirements. The purpose of recruiting is to find enough candidates to be able to choose the best. 
Selection is the process of using predetermined and standard methods and techniques for a particular job for choosing those who best meet its requirements. The candidate selection process can be defined as a process of assessing the ability of candidates based on pre-defined criteria and methods, to select the best candidates. The selection process aims to predict and maximise the future performance of employees and organizations. It's also important to note that external recruitment is only one option for solving resource shortfalls in the organization. (Klepić 2019)

According to Stoilkovska, Ilieva and Gjakovski (2015) the selection process consists of the following elements: the interest of the candidates for the job, review of the job, application forms, testing and interview, checking the accuracy of the information, feedback and job offer, medical examination and deployment and implementation at the workplace.

It is thought that selection is one of the most important parts in the successful management of human resources because it is the task of the selection process to find the right people for the right jobs. If this is not achieved, the organization will not be able to accomplish its mission, vision and objectives. (Stoilkovska et al. 2015).

Selection of human resources represents a decision made by the company i.e. a potential employer that performs the selection, which candidate has been selected, but also decision made by the candidate i.e. potential employee, whether he has selected the company and accepted the job for which he or she is competing, i.e. a job offered to him/her. Selection of human resources is a two-way process.

Numerous authors have analysed and researched what is attracting candidates to a particular company, which is the reason for talent to choose to hire in a particular company. The things that affect the employees' decisions about the right employer are also changing over time. Paterson reflects on Korn Ferry's study of 1,100 talent acquisition professionals which indicates that, unlike five years ago, compensation (i.e., salary and benefits) is no longer the top reason why candidates choose one employer over another. Nowadays, a company's culture is the number one factor. $\mathrm{He}$ believes that salary is still important and can help attract talent, but the overall impact is small and that the employer will not retain good people without commitment to positive culture and values, investing in improving the quality of senior management, and creating a career development opportunity (Paterson 2018). A review of the literature shows that there is a positive relationship between the amount of pay and applicant attraction.

Building an attractive job is very important: If a job was a product to be sold, job characteristics represent the features and capabilities of the product that the company is trying to sell. The challenge is to identify what job characteristics are likely to be universally attractive to job applicants and/or to engage in job design with the target 
audience in mind. Chapman et al.'s (2005) meta-analysis found that the location of an organization was a significant predictor of attraction $(>=.32)$, particularly for women. There are many reasons why location is important to job applicants. Proximity to family and friends, entertainment opportunities, lifestyle, spouse's job location, cost of living, school quality, crime rates, and so forth are all tied to where the organization is located (Nikolau \& Oostrom 2015).

According to Ehrhart and Ziegert (2005) researchers have distinguished between environmental and interactionist perspectives, insofar as perceptions of the organization's culture can have a main effect on organizational attraction, or they can interact with the cultural values held by potential applicants. Organizational characteristics such as organizational image, location, size, familiarity, reputation, industry, and profitability have all been shown to have significant influence during the recruitment process (Darnold \& Rynes 2013)

The very important factor for attracting a candidate is the employer brand. The Employer Brand is the perception that current and future employees have about the company's business as a workplace. According to Nikolau and Oostrom (2015) recruiting practice has perhaps changed more in the past six years than it changed in several decades preceding. Technology shifts, demographic changes, and the explosive growth of social media have transformed the recruiting function from simply posting job advertisements or attending career fairs to an ongoing flexible activity involving multiple sources and technologies.

\subsection{Creativity}

Human resources represent the most important resource of any enterprise and are recognized as the most important competitive advantage of enterprises in complex, heterogeneous, dynamic and uncertain business in a globalized world market.

Drucker (2005, p. 24) points out that a company (or any other institution) has only one true resource - the people. According to Bahtijarević-Šiber (1999, p. xviii) human resources represent the living factor of organization which increasingly contribute to achieving organizational objectives with their know-how, skills, capabilities and creativity.

A recent article in The Economist (Frymire 2006, p. 11) argues that the biggest challenge the organizations face today is not to find or hire cheap workers, but rather to hire individuals with "brainpower (both natural and trained) and especially the ability to think creatively". In essence, the argument was that if companies wanted to succeed in the global economy, they needed some individuals who had talent to develop new ideas, but also novel and useful approaches to their work. 
Creativity is the ability to look at a situation, things and phenomena from a new standpoint and find new, original solutions, i.e. the ability to look at things in a new, original way. Creativity is defined as the production of high quality, original, and elegant solutions to problems (Besemer \& O'Quin 1999; Christaans 2002; Ghiselin 1963; Mumford \& Gustafson 1988).

According to Vujić (2010, p. 194) creativity is a new and original way of thinking and acting, which always deviate from standard methods of searching for solutions for certain problem, situation or conflict.

Creativity and knowledge are the main challenges of modern business. Creative thinking leads to new knowledge, approaches and problem solving. (Ferreira \& Filho 2011)

According to Horng et al. (2015, p. 1353-1373) creativity represents the capability of creating new, original contents (ideas, concept, techniques, methods, models, products, organizations) which the environment will perceive as relevant and valuable for society. Nair and Gopal (2010) explain an organizational creativity as the mental capacity to generate new and useful ideas by individuals or a group of individuals working together and is therefore crucial to the long-term survival of the organization and its competitiveness.

According to Giura and Vasile (2017, p. 113-118) creativity is a vital source of organization in time when the innovation is a key factor in everything referring to business performance, as well as non-profit activities. Therefore, it is necessary to focus the organizational management on those factors which encourage creative manifestation of human resources on every level in all organizational processes.

Creativity is truly a multi-level construct in that creativity as well as both a process and an outcome are meaningful at different levels of analysis (Chen et al. 2004). For example, as an outcome creativity refers to the production of novel and useful products or services by an individual, a group, or an organization. In contrast, creative processes refer to the steps taken or creative acts that result in an outcome. Creative processes can also be undertaken at all three levels of analysis (Zhou \& Shalley 2007, p. 305): individual, team and organizational.

According to Buble and Klepić (2009, p. 109) creative ability is the result of the existence of other abilities along with a number of other personality traits, the existence of certain knowledge, motivation, but also other factors. According to Goldstein (2016), creativity in the organization is the driver of innovation and a key factor in the development of personal, professional, entrepreneurial and social skills.

Numerous scientific but also practical researches have focused on what creativity means in organizational environment and what leads employees and teams to be creative at work. 
Research results have shown that individual differences, management practices, feedback from leaders and co-workers, social networks, and the organizational climate, along with many other factors can either stifle or enhance creativity at work (e.g., Amabile 1996; Gilson \& Shalley 2004; Gough 1979; Scott \& Bruce 1994; Tierney \& Farmer 2002; Zhou 1998).

Creativity, requires individuals with creative characteristics, who feel free from threat and pressure, and who work in a supportive environment. The innovation process begins with the creativity of individuals so the generation of a new idea is a cognitive process located within individuals, albeit fostered by interaction processes, for example, in teams (Mumford \& Gustafson 1988). Creative cognitions occur when individuals feel "free from pressure, safe, and positive" (Claxton 1997). High levels of stress lead to a reliance on habitual solutions. (Zhou \& Shalley 2007, p. 215). A large majority of authors agree that the environment is very important for creative process (Zhu, Bilton \& Cummings 2014; Andriopulos 2001; Cummings 1965).

A great deal of the theoretical and empirical work in the creativity arena opens by stating that creativity should significantly increase performance; it should be a driver of team effectiveness, and be positively associated with organizational change and success (Zhou \& Shalley 2007, p. 304).

At the individual level of analysis, researchers claim that individuals range in their creative abilities and the jobs range in their levels of required creativity and that when those two complement each other, higher levels of positive effect ensue (Livingstone et al. 1997; Scott \& Bruce 1994; Shalley et al. 2000). In contrast, at the group level of analysis, researchers have focused their attention to more objective outcomes finding that creativity is positively related to performance. (Gilson et al. 2005; West \& Anderson 1996).

By encouraging creativity in organizations, it is possible to achieve some competitive advantage and to elevate organization from the mediocre to the excellent organizations.

Wong and Pang (2003) consider that creativity together with innovation is the most important factor in an organization's success.

\subsection{Small and Medium Enterprises}

Small and medium enterprises represent more than $99 \%$ of the total number of enterprises and employ almost $70 \%$ of the total number of employees. Small and medium enterprises are the main drivers of innovation, employment and social and local integration in Europe. 
In many of its documents, the European Union has put small and medium enterprises at the top of their priorities, which emphasizes the need to help this sector.

Bosnia and Herzegovina is a complex state that consists of two Entities, the Federation of Bosnia and Herzegovina and Republika Srpska, and the Brčko District. The definition of small and medium-sized enterprises is not fully harmonized and each entity as well as the Brčko District has its definition and classification.

According to the Law on the promotion of small businesses, small and medium enterprises in the Federation of Bosnia and Herzegovina consist of "small business entities, physical and juridical persons who permanently carry out activities permitted by law to gain profit or income, including self-employment and family affairs related to crafts and other activities, registered with the authorities, regardless of the form of organization, and which: are independent in business, employ less than 250 persons annually and realize an annual turnover up to 40 million $\mathrm{KM}$ and/or whose annual balance sheet does not exceed 30 million KM."4 In the Republic of Srpska, small and medium-sized enterprises are defined by the Law on Incentives for Small and Medium Enterprises. Classification of small and medium enterprises and micro enterprises within small businesses is the same as in the Federation of Bosnia and Herzegovina, and the difference is in the classification given the amount of income realized and the balance Sheet.5 The Brčko District is defined in a similar way and the differences refer to the classification according to the total revenue and the balance Sheet. 6

Table 1: Classification of SME-s in Bosnia and Herzegovina

\begin{tabular}{|c|r|r|r|r|r|r|r|r|}
\hline \multirow{2}{*}{$\begin{array}{c}\text { Classification } \\
\text { criteria }\end{array}$} & \multicolumn{2}{|c|}{ Federation of BH } & \multicolumn{2}{c|}{ Republic of Srpska } & \multicolumn{2}{c|}{ District Brčko } \\
\cline { 2 - 9 } & \multicolumn{2}{|c|}{ Small } & Medium & \multicolumn{2}{c|}{ Small } & Medium & Small & Medium \\
\hline & Micro & Small & & \multicolumn{1}{c|}{ Micro } & Small & & & \\
\hline $\begin{array}{c}\text { Number of } \\
\text { employers }\end{array}$ & $1-9$ & $10-49$ & $50-249$ & $1-9$ & $10-49$ & $50-249$ & $1-49$ & $50-249$ \\
\hline $\begin{array}{c}\text { Income in } \\
\text { KM (000) }\end{array}$ & 400 & 4.000 & 30.000 & & 10.000 & 50.000 & 2.800 & 11.000 \\
\hline $\begin{array}{c}\text { Balance Sheet } \\
\text { (Assets) in } \\
\text { KM (000) }\end{array}$ & 400 & 4.000 & 40.000 & & 10.000 & 43.000 & 1.400 & 5.500 \\
\hline
\end{tabular}

Source: Research of the Author in the Laws of Bosnia and Herzegovina

4 Zakon o poticanju razvoja malog gospodarstva, Službene novine Federacije BiH, no. 19/06.

5 Zakon o poticanju razvoja malih i srednjih preduzeća, Službeni glasnik Republike Srpske“, broj: 64/02, 34/06 i 119/08

6 Zakon o poduzećima Brčko Distrikta Bosne i Hercegovine, usvojen 29.11.2011. godine, pristupljeno 3.5.2019. https://skupstinabd.ba/3-zakon/hr/Zakon\%20o\%20poduzec-ima\%20Brc--ko\%20 Distrikta\%20BiH/002\%2049-11\%20Zakon\%20o\%20poduzec-ima\%20Brc--ko\%20distrikta\%20 $\mathrm{BiH}, \% 20$ proc--is--c-en\%20tekst.pdf 


\subsection{Setting Hypothesis}

The defined problem has also defined the underlying objective of this research, which is to gain insight into the correlation of the recruitment and selection of human resources and creativity of small and medium-sized enterprises. The sub-objectives of this research are to determine whether there is a correlation between recruitment and selection of human resources and individual, team and organizational creativity, and whether there is a difference in the correlation between recruitment and selection of human resources and creativity with regard to the size of the enterprise, i.e. in small and in medium sized enterprises.

The problem and the objectives set for this study determined the content of the three hypotheses which state:

H 1 - "There is a significant positive correlation between recruitment of human resources and creativity in SMEs."

H 1.1. - "There is a significant positive correlation between recruitment of human resources and individual creativity in SMEs."

H 1.2. - "There is a significant positive correlation between recruitment of human resources and team creativity in SMEs."

H 1.3. - "There is a significant positive correlation between recruitment of human resources and organizational creativity in SMEs."

H 2 - "There is a significant positive correlation between selection of human resources and creativity in SMEs."

H 2.1. - "There is a significant positive correlation between selection of human resources and individual creativity in SMEs."

H 2.2. - "There is a significant positive correlation between selection of human resources and team creativity in SMEs."

H 2.3. - "There is a significant positive correlation between selection of human resources and organizational creativity in SMEs."

H 3 - There is a difference in the correlation between recruitment and selection of human resources and creativity in small and medium-sized enterprises in terms of their size. 
Figure 1 presents the model of the correlation between the recruitment and selection of human resources and creativity of small and medium-sized enterprises.

Figure 1: A Schematic presentation of the model of the correlation between the recruitment and selection of human resources and creativity of small and medium-sized enterprises

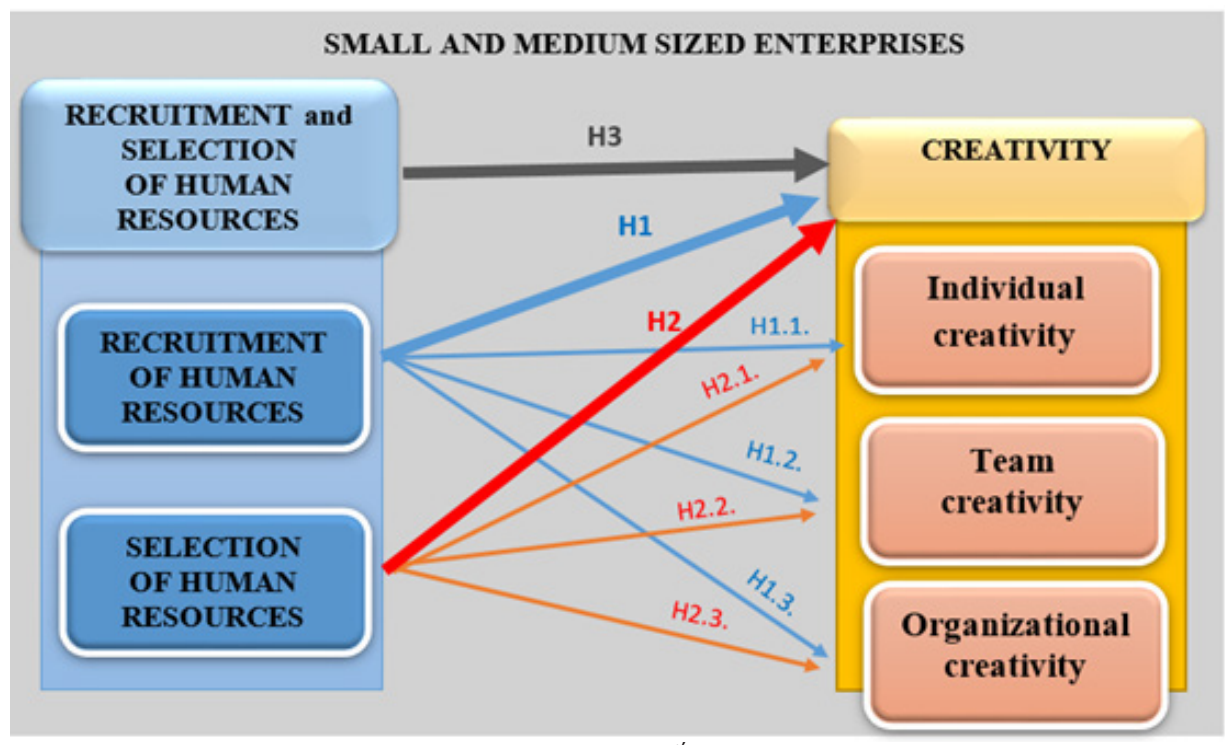

\section{Methodology of Research}

\subsection{The scope of the research, methods of collecting and processing data model}

The empirical research was conducted in the Federation of Bosnia and Herzegovina, more specifically, in the area of Herzegovina during the months of April and May in the year 2019. For participation in the study, 73 enterprises were called and 32 participated (response rate was $43.8 \%$ ). According to the distribution of the enterprises, based on the size of the enterprise, the sample consisted of $18(56.2 \%)$ small and 14 (43.8\%) medium-sized enterprises. The criterion for defining SME-s was one-dimensional. Small businesses are those up to 49 employees and medium between 50 and 249 employees.

For the study an original questionnaire was created, which consisted of three parts. In the first part of the questionnaire, basic questions were asked about the companies while in the second part of the questionnaire questions were asked about recruitment and selection of human resources in the companies. 
In order to measure and evaluate the recruitment and selection of human resources, Likert scale type 1 to 5 is offered for answers of questions.

The third part of the questionnaire focused on the evaluation of the creativity of the enterprise that included individual, team creativity, and organizational creativity in the period of time from 2015 to 2019. The degree to which the participant agreed with the said statement ranged from 1 to 5 with the following interpretations of the grades: 1 - Strongly disagree; 2 - Disagree; 3 - Neither agree nor disagree; 4 - Agree, 5 - Strongly agree (Likert scale of agreement).

The questionnaire was created using the Google forms option and the link to the survey questionnaire was sent to companies via mail. Enterprise responses were recorded in Microsoft Excel. The data collected was encoded and entered into the SPSS database. The data was analysed in IBM SPSS Statistic 25.0. Shapiro-Wilk test was used for normality testing. Variables that did not deviate from the normal distribution are expressed as mean (standard deviation), and as median [interquartile range]. The Pearson correlation coefficient and the t-test for independent samples (if the variables did not deviate from the normal distribution) and the Spearman correlation coefficient and Mann-Whitney $U$ test (if the variables deviated from the normal distribution) were used to evaluate the correlation and test the significance of the differences. The statistical significance limit was set at $\mathrm{p}=0.05$.

\subsection{Operationalization of Variables}

The variable in hypothesis $\mathrm{H} 1$ is the recruitment of human resources. It was measured by subjective assessment of the following indicators: human resource planning, recruitment way of human resources, sources of information of candidates, techniques and activities used for attracting quality staff, incorporating employees into attracting talent and activities during the advertising and searching for the job candidates.

The variable in hypothesis $\mathrm{H} 2$ is the selection of human resources. It was measured by subjective assessment of the following indicators: persons in charge for testing and selection of human resources, methods used for selection, types of testing used in the process of selection and types of interviews used in the process of selection and checking the past of job applicants.

The variables in hypothesis $\mathrm{H} 3$ are also the recruitment and selection of human resources and creativity.

The variable organizational creativity in hypotheses was measured through individual, team and organizational creativity. Individual creativity of employees is measured by setting questions which refer to personal characteristics and work environment characteristics that encourage individual creativity. Team creativity was measured 
by setting questions which refer to the role of work teams in encouraging creativity. Examinees stated their opinions on questions such as the manner of communication within the team, procedures for team decision making, sharing ideas within team members and the size of the team. Indicators of organizational creativity are organizational methods of encouraging the creation and sharing of ideas, cooperation between certain sections, reward system and similar.

\section{Research Results and Discussion}

The results of the research on the characteristics of the enterprises involved in the research are presented in the table 2.

Table 2: Sample Characteristics

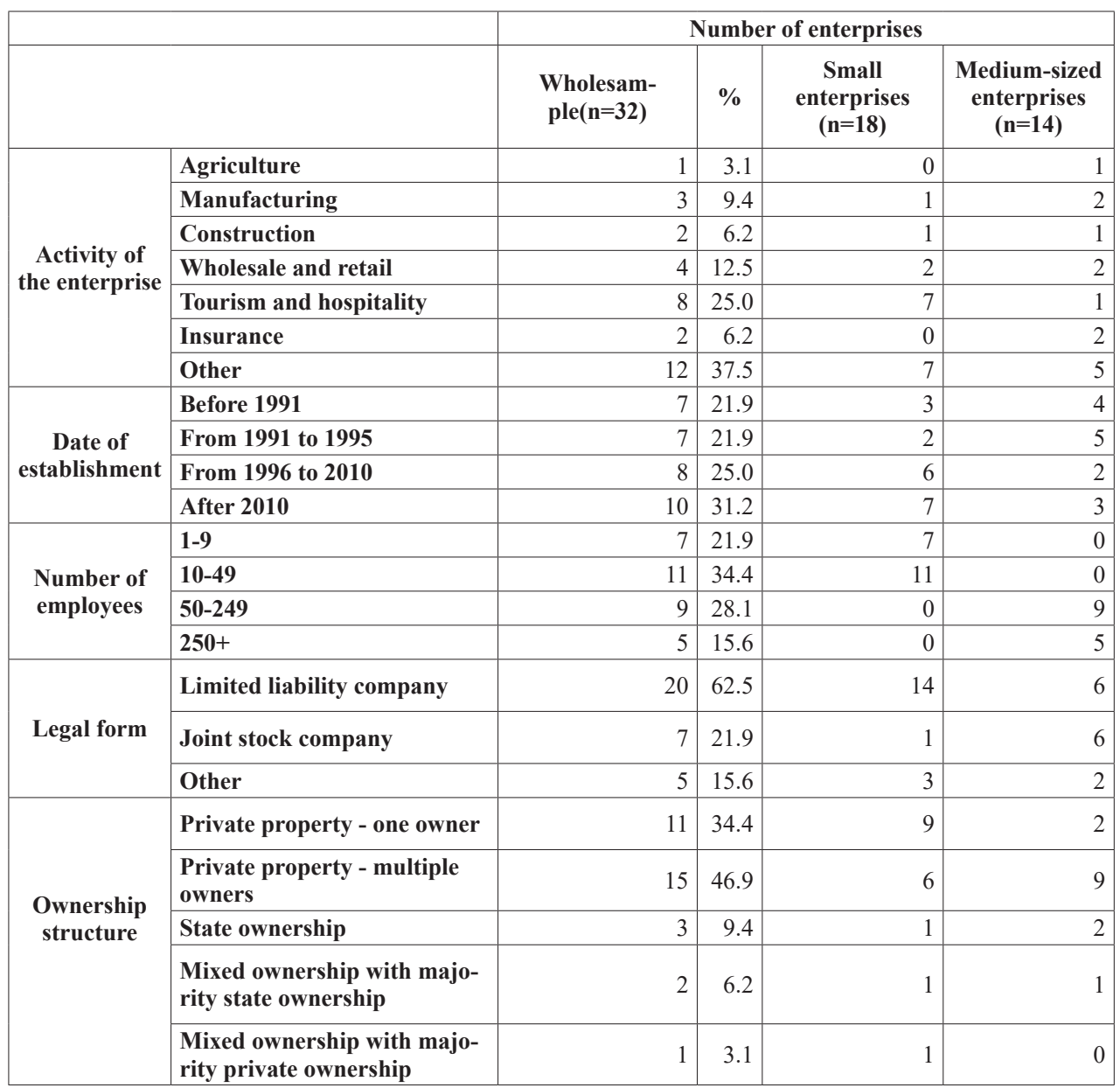

Source: Research of the Author 
The largest number of companies (31.2\%) was founded after 2010 and then from 1996 to $2010,25 \%$ of them.

With regard to the number of employees, $56.2 \%$ of them are small businesses, those with less than 50 employees, while $43.8 \%$ of them are medium-sized companies with between 50 and 250 employees.

The largest share of the researched companies has $25 \%$ tourism and hospitality, followed by Wholesale and retail of $12.5 \%$, and Manufacturing.

Most companies (62.5\%) are legally organized as a limited liability company. In private ownership is $81.3 \%$ of all researched companies, while $34.4 \%$ of companies have one owner and the $46.9 \%$ of them has multiple owners.

Table 2 shows the average grades for Human Resources Management activities (recruitment and selection of human resources) in the surveyed SMEs in the Federation of Bosnia and Herzegovina. The results are presented for the whole sample, but also by the size of the enterprise, with testing the differences in ratings with regard to the size of the enterprise.

Table 3: Assessment of recruitment and selection activities in the surveyed SMEs

\begin{tabular}{|c|c|c|c|c|}
\hline & $\begin{array}{c}\text { Whole sample } \\
(n=32)\end{array}$ & $\begin{array}{l}\text { Small enterprises } \\
\quad(n=18)\end{array}$ & $\begin{array}{c}\text { Medium-sized } \\
\text { enterprises }(n=14)\end{array}$ & pa \\
\hline \multicolumn{5}{|l|}{ HRM activities } \\
\hline Recrutiment & $3,47(0,56)$ & $3,38(0,53)$ & $3,59(0,60)$ & 0,314 \\
\hline Selection & $3,11(0,81)$ & $2,97(0,87)$ & $3,28(0,72)$ & 0,286 \\
\hline
\end{tabular}

Source: Research of the Author

According to the results of the research, no significant difference was found in the evaluation of Human Resources management activities (recruitment and selection of human resources) between SMEs ( $p>0.05$ ). Despite this, the average grades still indicate some minor differences.

The average grades for recruitment and selection of human resources are slightly higher in the medium-sized enterprise group compared to the small enterprises.

It can also be seen from the results obtained that the grades for the selection of human resources are slightly lower than the grades for the recruitment activities, which means that in SMEs these activities are given more attention.

Table 3 shows the average grades for creativity in the surveyed SMEs in the Federation of Bosnia and Herzegovina. The results are presented for the whole sample, for the individual, team and organizational creativity but also by the size of the company, with testing of differences in grades for the size of the company. 
Table 4: Creativity assessment in the surveyed SMEs

\begin{tabular}{|ccrrr|}
\hline & $\begin{array}{c}\text { Whole sample } \\
(\mathbf{n}=\mathbf{3 2})\end{array}$ & $\begin{array}{c}\text { Small enterprises } \\
(\mathbf{n}=\mathbf{1 8})\end{array}$ & $\begin{array}{c}\text { Medium-sized } \\
\text { enterprises }(\mathbf{n}=\mathbf{1 4})\end{array}$ & pa \\
\hline Creativity & & & & \\
\hline Individual (IC) & $3,97(0,45)$ & $3,92(0,44)$ & $4,03(0,48)$ & 0,519 \\
\hline Team (TC) & $3,85(0,51)$ & $3,85(0,47)$ & $3,86(0,57)$ & 0,969 \\
\hline Organizational (OC) & $3,95(0,60)$ & $3,93(0,52)$ & $3,97(0,71)$ & 0,840 \\
\hline
\end{tabular}

The results are expressed as arithmetic mean (standard deviation) at for independent samples

Source: Research of the Author

According to the results of the research, no significant difference in creativity was found between SMEs ( $p>0.05$ ). However, even here average grades indicate some differences.

In both cases, the average grades of all aspects of creativity are around 4, which, analysed in the context of the researched claims, shows that the companies support the freedom of presenting new ideas, nurture teamwork, approach problems rationally, support individual diversity and open communication between employees.

Table 4 shows the correlation coefficients between staffing (recruitment and selection of human resources) and creativity, for the whole sample and with regard to the company size.

Table 5: Correlation between staffing (recruitment and selection of human resources) and creativity

\begin{tabular}{|l|r|r|r|}
\hline \multicolumn{1}{|c|}{ Whole sample } & $\begin{array}{c}\text { Individual } \\
\text { creativity (IC) }\end{array}$ & $\begin{array}{c}\text { Team } \\
\text { creativity(TC) }\end{array}$ & $\begin{array}{c}\text { Organizational } \\
\text { creativity (OC) }\end{array}$ \\
\hline Staffing - recruitment & & & $0,511^{* *}$ \\
Staffing - selection & $0,553^{* *}$ & $0,499^{* *}$ & $0,585^{* *}$ \\
\hline \multicolumn{1}{|c|}{ Small enterprises } & $0,465^{* *}$ & $0,510^{* *}$ & $0,481^{*}$ \\
\hline Staffing - recruitment & 0,258 & 0,289 & $0,639^{* *}$ \\
Staffing - selection & 0,249 & 0,386 & $0,544^{*}$ \\
\hline \multicolumn{1}{|c|}{ Medium-sized enterprises } & & & $0,571^{*}$ \\
\hline Staffing - recruitment & $0,842^{* *}$ & $0,712^{* *}$ & \\
Staffing - selection & $0,757^{* *}$ & $0,712^{* *}$ & \\
\hline **. Correlation significant at the 0.01 level \\
*. Correlation significant at the 0.05 level \\
The numbers represent Pearson's correlation coefficient
\end{tabular}

Source: Research of the Author 
The results of the correlation analysis show that throughout the sample, a significant, positive correlation exists between both staffing functions and all three aspects of creativity.

In the group of small enterprises, a significant, positive correlation was found between recruitment and selection functions and organizational creativity, while in the group of medium-sized enterprises as well as in the whole sample, a significant, positive correlation was found between both staffing functions and all three aspects of creativity (individual, team, organizational).

In accordance with the results obtained in this research, it can be stated that the hypothesis $\mathbf{H} 1$ set in this research has been fully confirmed - "There is a significant positive correlation between recruitment of human resources and creativity in SMEs."

It can also be stated that each of the three additional hypotheses $(\mathrm{H}$ 1.1., $\mathrm{H}$ 1.2. and H 1.3.) were confirmed and, in accordance with the obtained results of the research, it was confirmed that a correlation between recruitment of human resources and all three types of creativity (individual, team and organizational creativity) of small and medium enterprises existed.

According to research results it can be stated that the hypothesis $\mathrm{H} 2$ set in this research has been fully confirmed - "There is a significant positive correlation between selection of human resources and creativity in SMEs."

It can also be stated that each of the three additional hypotheses (H 2.1., H 2.2. and H 2.3.) were confirmed and, in accordance with the obtained results of the research, it was confirmed that a correlation between selection of human resources and all three types of creativity (individual, team and organizational creativity) of small and medium enterprises existed.

The analysis of the data shows that there is a significant correlation for the total sample of small and medium-sized enterprises, as well as for the set of medium-sized enterprises with all three aspects of creativity, individual, team and organizational. However, if only a set of small enterprises is observed, then there is a significant positive correlation only with organizational creativity, while with individual and team creativity there is a correlation, but it is not significant.

In accordance with the results obtained in this research, it can be stated that the hypothesis $\mathbf{H ~} \mathbf{3}$ set in this research has been fully confirmed - "There is a difference in the correlation between recruitment and selection of human resources and creativity in small and medium-sized enterprises in terms of their size." 


\section{CONCLUSION}

As the global economy encourages increasingly fierce competition, organizational leaders are thinking hard about what they can do to give their organizations a competitive advantage. They recognized the importance of human resources and that they could be conceptualized as a critical, competitive advantage for an organization. Human resources are the total knowledge, skills, capability, creativity, motivation and loyalty one organization has at its disposal. Not only in practice but also in theory, creativity is recognized as one of the most important dimensions of human resources, having a significant influence on achieving goals and organizational competitiveness.

Human Resource Management is one of the most important business functions and it represents a series of related activities and tasks of management and organizations aimed at ensuring adequate number and structure of employees, their knowledge, skills, interests, motivation and behaviour needed to achieve current, developmental and strategic goals of the organization.

Recruitment and selection of human resources are very important for small and medium enterprises as well as for large ones. SMEs face great difficulties in finding qualified persons for their vacancies, due to both lack of attractiveness of the jobs offered in SMEs and low quality of the recruiting practices. Since the quality of the recruitment process is crucial for the effectiveness of the employee selection, and the selection is crucial for innovation, creativity, and the business results of employees and organizations, SMEs need to invest more resources in recruiting good candidates.

Creativity is viewed as the production of new and useful ideas or solutions. It is viewed and analysed on three levels: individual, team and organizational level. Individual creatives are part of creative groups/teams, and creative teams are part of an innovative organization that is encouraged by executives with specific characteristics, such as emotional intelligence, charisma and willingness to change, foster, motivate, reward, and create an innovative organizational climate and culture.

Creativity is especially significant to small and medium enterprises. SMEs dispose of limited resources and factors which can distinguish them on the global market and make them competitive are some creative and innovative employees.

The results of this research show that a significant positive correlation exists between recruitment and selection of human resources and creativity in SMEs in Herzegovina Region. The results also show that recruitment and selection of human resources are more advanced in the medium-sized enterprise group compared to the small enterprises, and that there is a stronger correlation between recruitment and selection of human resources in medium-sized enterprises and creativity. 
Researched enterprises show large grades for all types of creativity and that companies support the freedom of presenting new ideas, nurture teamwork, approach problems rationally, support individual diversity and open communication between employees. According to the results obtained, it was also found that there is a significant positive correlation between recruitment and selection of human resources and all three types of creativity (individual, team and organizational).

Organizations should create environment where employees are free to create, innovate, experiment and take limited and reasonable risk and to create organizational climate and build organizational culture which will be encouraging for any individual, team and organizational creativity.

The results can be used for the management of SMEs and departments of human resource management. The obtained results clearly and unequivocally point to the need to develop a human resources management function in enterprises, and in this context, that special attention is paid to recruitment and selection of human resources, because by finding, selecting and employing competitive staff, enterprises are able to achieve their business objectives and compete with competition and ensure survival and development. Enterprises with higher-quality attractiveness and staff selection achieve better creativity and innovation results.

The results of past research on creativity, as well as this research, provide guidelines and recommendations to managers and owners of SMEs, that it is important to recognize, encourage, develop and reward creative workers. In order to do this, it is necessary to create a creative climate and other conditions necessary for the implementation of creativity. Existing research indicate that creativity is released in environments characterized by diversity of participants, freedom to share knowledge and ideas, and a system of appropriate incentives. With more choices and high expectations of job, quality employees more carefully than ever are studying potential employers. HRM and organization should provide employees with flexibility, good pay, career development and advancement, organizational culture, additional values and learning culture. Doing so will attract quality candidates, develop them, and retain them, but also create better business results.

A recommendation for any future research is to enlarge the sample size and to conduct a research on a large number of enterprises. On the other hand, the research should be repeated in a certain period of time in order to see the changes and make a comparison. A suggestion for future research is to make comparison with large enterprises or to make a similar research conducted on company employees, since the research focuses only on the management of organizations. 


\section{REFERENCES}

1. Amabile, T. M., Conti, R., Coon, H., Lazenby, J. and Herron, M. 1996. Assessing the Work Environment for Creativity. Academy of Management Journal, pp. 39.

2. Andriopoulos, C., 2001. Determinants of organisational creativity: a literature review. Management Decision, 39, pp. 834-840.

3. Bahtijarević-Šiber, F., 1999. Management ljudskih potencijala. Zagreb: Golden marketing.

4. Barber, A. E., 1998. Recruiting employees: Individual and organizational perspectives. Thousand Oaks, CA: Sage Publications, Inc.

5. Besemer, S. P., and O'Quin, K., 1999. Confirming the three-factor creative product analysis matrix model in an American sample. Creativity Research Journal, 12, pp. 287-296.

6. Boudreau, J. W., and Rynes, S. L., 1985. Role of recruitment in staffing utility analysis. Journal of Applied Psychology, 70, pp. 354-366.

7. Buble, M., and Klepić, Z. (2009). Menadžment malih poduzeća - osnove menadžmenta. Mostar: Ekonomski fakultet Sveučilišta u Mostaru.

8. Carroll, M., Marchington, M., Earnshaw, J., and Taylor, S., 1999. Recruitment in small firms: processes, methods and problems. Employee Relations, 21(3), pp. 236-250.

9. Chapman, D. S., Uggerslev, K. L., Carroll, S. A., Piasentin, K. A., and Jones, D. A., 2005. Applicant attraction to organizations and job choice: A meta-analytic review of the correlates of recruiting outcomes. Journal of Applied Psychology, 90, pp. 928-944.

10. Chen, G., Mathieu, J. E., and Bliese, P. D., 2004. A framework for conducting multi-level construct validation. Research in Multi-Level Issues, 3, pp. 273-303.

11. Christiaans, H. H. C. M., 2002. Creativity as a design criterion. Creativity Research Journal. 14, pp. 41-54.

12. Claxton, G. L., 1997. Have brain, tortoise mind: Why intelligence increases when you think less. London, UK: Fourth Estate

13. Cooke, F.L., 2005. HRM - work and employment in China. London: Routledge.

14. Cummings, L., 1965. Organizational Climates for Creativity. The Academy of Management Journal, 8. 
15. Darnold, T. C., and Rynes, S. L., 2013. Recruitment and job choice research: Same as it ever was? In N. W. Schmitt, S. Highhouse, \& I. B. Weiner, Eds. Handbook of psychology: Industrial and organizational psychology. $2^{\text {nd }}$ ed. Hoboken, NJ: John Wiley \& Sons Inc. pp. 104-142.

16. Drucker, P., 2005. Najvažnije o menadžmentu. Zagreb: MEP Consult.

17. Ehrhart, K. H., and Ziegert, J. C., 2005. Why are individuals attracted to organizations? Journal of Management, 31, pp. 901-919.

18. Ferreira, N. W., and Filho, F.S., 2011. Innovation in business. World Academy of Science, Engineering and Techhnology, 78, pp. 614-619

19. Ghiselin, B., 1963. Ultimate criteria for two levels of creativity. In Taylor, C. W. and Barron, F. (Eds.), Scientific creativity: Its recognition and development. New York, NY: Wiley. pp. 30-43

20. Gilbert, J., and Jones, G., 2000. Managing human resources in New Zealand small business. Asia Pacific Journal of Human Resources, 38(2), pp. 55-68.

21. Gilson, L. L., Mathieu, J. E., Shalley, C. E., and Ruddy, T. M., 2005. Creativity and standardization: Complementary or conflicting drivers of team effectiveness?. Academy of Management Journal, 48, pp. 521-531.

22. Goldstein, S. (2016) Poduzetništvo u kreativnim industrijama. Zagreb: Hrvatska sveučilišna naklada.

23. Goldstein, H. W., Pulakos, E. D., Passmore, J., and Semedo, C., 2017. The Wiley Blackwell handbook of the psychology of recruitment, selection and employee retention. UK: John Wiley \& Sons Ltd

24. Gough, H. G., 1979. A creative personality scale for the Adjective Check List. Journal of Personality and Social Psychology, 37, pp. 1398-1405.

25. Guira, A., and Vasile, M., 2017. Organizational Entropy and Creative Potential. Quality-Access to Success, 18 (157), pp. 113-118

26. Heneman, H., and Berkely, R., 1999. Applicant attraction practices and outcomes among small businesses. Journal of Small Business Management, 37(1), pp. $53-74$.

27. Horng, J. S., Tsai, C. Y., Liu, C. H., and Chung, D. Y. C., 2015. Measuring Employee's Creativity: A New Theoretical Model and Empirical Study for Tourism Industry. Asia Pacific Journal of Tourism Research, 20 (12), pp. 1353-1373 
28. Hornsby, J., and Kuratko, D., 2003. Human resource management in US small business: A replication and extension. Journal of Developmental Entrepreneurship, 8(1), pp. 73-92.

29. Klepić, I., 2019. Correlation of Recruitment and Selection of Human Resources and the Performance of Small and Medium Enterprises. Naše gospodarstvo/Our Economy, 65 (4), pp. 14-26. doi: 10.2478/ngoe-2019-0016

30. Kotey, B., and Sheridan, A., 2001. Gender and the practice of HRM in small business. Asia Pacific Journal of Human Resources, 39(3), pp. 23-40.

31. Lesko Bošnjak, L., and Klepić, Z., 2013. Osnove menadžmenta ljudskih potencijala. Mostar: Ekonomski fakultet Sveučilišta u Mostaru.

32. Livingstone, L. P., Nelson, D. L., and Barr, S. H., 1997. Person-environment fit and creativity: An examination of supply-value and demand-value ability versions of fit. Journal of Management, 23, pp. 119-146.

33. Michaels, E., Handfield-Jones, H., and Axelrod Michaels, B., 2001. The war for talent. Boston, MA: Harvard Business School Press.

34. Mumford, M. D., and Gustafson, S. B., 1988. Creativity syndrome: Integration, application, and innovation. Psychological Bulletin, 103, pp. 27-43.

35. Nair, K. K., and Gopal, R. R., 2010. Advocating Different Paradigms: Relevance of Workplace Creativity. SIES Journal of Management, 7 (2), 142-150.

36. Newman, A., and Sheikh, A. Z. 2014. Determinants of best HR practices in Chinese SMEs. Journal of Small Business and Enterprise Development, 21(3), pp. 414-430.

37. Nikolau, I., and Oostrom, J.K., 2015. Employee recruitment, selection and assessment-Contemporary issues for theory and practice. East Sussex: Psychology Press.

38. Paterson, K., 2018. Winning the race for talent part one. Rough Notes. Retrieved from http://roughnotes.com/winning-the-race-for-talent-part-one/

39. Raghavi, K., and Gopinathan, N., 2013. Role of human resources as change agent in enabling equal opportunity practices. Journal of Economics, Business and Management, 1(3), pp. 300-303.

40. Rynes, S. L., 1989. The employment interview as a recruitment device. In Eder, R. W., and Ferris, G. R. eds. The employment interview: Research and practice Beverly Hills, CA: Sage. pp. 127-141. 
41. Scott, S. G., and Bruce, R. A., 1994. Determinates of innovative behavior: A path model of individual innovation in the workplace. Academy of Management Journal, 137, pp. 580-607.

42. Scott, S. G., and Bruce, R. A. 1994. Determinates of innovative behavior: A path model of individual innovation in the workplace. Academy of Management Journal, 137, pp. 580-607.

43. Shalley, C. E., and Gilson, L. L., 2004. What leaders need to know: A review of social and contextual factors that can foster or hinder creativity. The Leadership Quarterly, 15(1), pp. 33-53.

44. Shalley, C. E., Gilson, L. L., and Blum, T. C., 2000. Matching creativity requirements and the work environment: Effects on satisfaction and intent to turnover. Academy of Management Journal, 43, pp. 215-224.

45. Sikavica, P., Bahtijarević-Šiber, F., and Pološki-Vokić, N., 2008. Temelji menadžmenta. Zagreb: Školska knjiga.

46. Stoilkovska, A., Ilieva, J., and Gjakovski, S., 2015. Equal employment opportunities in the recruitment and selection process of human resources. UTMS Journal of Economics, 6(2), pp. 281-292.

47. Tierney, P., and Farmer, S. M., 2002. Creative self-efficacy: Its potential antecedents and relationship to creative performance. Academy of Management Journal, 45(6), pp. 1137-1148.

48. Vicari, S., 1998. La creatività dell'impresa: Tra caso e necessità. Italy: Etaslibri.

49. Vujić, V., 2010. Poduzetništvo i menadžment u uslužnim djelatnostima. Rijeka: Fakultet za menadžment u turizmu i ugostiteljstvu Opatija.

50. West, M. A., and Anderson, N., 1996. Innovation in top management teams. Journal of Applied Psychology, 81, pp. 680-693.

51. Wong, C. S., and Pang, W. L., 2003. Barriers to Creativity in the Hotel IndustryPerspectives of Managers and Supervisors. International Journal of Contemporary Hospitality Management, 15(1). Pp. 29-37.

52. Wong, C. S., and Pang, W. L., 2003. Motivators to creativity in the hotel industry - perspectives of managers and supervisors. Tourism Management, 24, pp. 551-559.

53. Zahaire, M., and Osoian, C., 2013. Job recruitment and selection practices in small and medium organizations. Studia Ubb, Oeconomica, 58(2), pp. 89. 
54. Zhou, J., 1998. Feedback valence, feedback style, task autonomy, and achievement orientation: Interactive effects on creative performance. Journal of Applied Psychology, 83, pp. 261-276.

55. Zhou, J., and Shalley, C. E., 2007. Handbook of Organizational Creativity. New York, USA: Lawrence Erlbaum Associates - Taylor \& Francis Group.

56. Zhu, Z., Bilton, C., and Cummings, S., 2014. Creative management in practice: bisociation with „timely balance “. Handbook of Management and Creativity, pp. 369-385

ATTACHMENT: QUESTIONNAIRE

https://drive.google.com/file/d/1fIDu_WtAgJ8_hdXZdBOK47jey1R93pow/ view?usp=sharing 
Iva Klepić

Mirela Mabić

Danijela Madžar

\section{PRIBAVLJANJE I SELEKCIJA LJUDSKIH RESURSA I ORGANIZACIJSKA KREATIVNOST U MALIM I SREDNJIM PODUZEĆIMA}

\section{SAŽETAK}

U modernim uvjetima poslovanja ljudski resursi postali su najvažniji resurs poduzeća a mnogi autori ističu da to posebno vrijedi za mala i srednja poduzeća u kojima, zbog svoje specifičnosti, ljudski resursi stvaraju konkurentsku prednost poduzeća $i$ utječu na njegov opstanak i razvoj.

MSP se suočavaju s jakom, globalnom konkurencijom velikih poduzeća i da bi preživjela i rasla na tržištu, moraju pronaći specifične snage u sebi, razvijati ih $i$ koristiti ih. Kreativnost je jedan od najmoćnijih alata koji MSP-u omogućuju konkurentnost, opstanak i razvoj na tržištu.

Osnovni cilj ovog istraživanja je utvrditi postoji li povezanost između pribavljanja i selekcije ljudskih resursa i organizacijske kreativnosti u malim i srednjim poduzećima.

Istraživanje je provedeno u MSP-u u Federaciji BiH u 2019.godini. Za istraživanje je kreiran originalan upitnik koji je prikupio mišljenja top menadžera o pribavljanju $i$ selekciji ljudskih resursa i organizacijskoj kreativnosti u malim i srednjim poduzećima.

Podaci su analizirani pomoću IBM SPSS Statistic 25.0. Od statističkih metoda korištene su sljedeće: Shapiro-Wilkov test, Pearsonov koeficijent korelacije, Mann-Whitney $U$ test $i$ t-test za neovisne uzorke.

Rezultati istraživanja pokazali su da postoji povezanost između pribavljanja i selekcije ljudskih resursa i organizacijske kreativnosti u MSP-u. Rezultati istraživanja također su pokazali da postoje razlike u povezanosti između pribavljanja i selekcije ljudskih resursa i organizacijske kreativnosti u poduzećima s obzirom na njihovu veličinu.

Ključne riječi: kreativnost, ljudski resursi, pribavljanje, mala i srednja poduzeća, selekcija,

JEL: $M 12, M 51,015$ 